\title{
Clinical and demographic features of HIV infection in El Salvador
}

\author{
Elisa García Vázquez, ${ }^{1}$ Rolando A. Cedillos, ${ }^{2}$ \\ and David A. Wheeler ${ }^{3}$
}

ABSTRACT Objective. To understand some of the clinical and demographic features of the epidemic of infection by HIV in El Salvador prior to the availability of antiretroviral therapy in that country. Methods. We conducted a retrospective review of HIV-infected individuals who were admitted to Hospital Rosales, which is a large public teaching hospital in San Salvador, El Salvador, during the 5-year period of 1994 through 1998. Chart abstraction was done of 194 out of the 208 individuals admitted to the Infectious Diseases Unit at Hospital Rosales (14 charts could not be located). We also carried out a sampling of other HIV-infected adults treated in other parts of the hospital.

Results. Of the 250 patients whose records we reviewed, $67 \%$ were men and $86 \%$ were from an urban area. The mean age at HIV diagnosis was 34 years. In terms of occupation, $50 \%$ of the men were day laborers; $76 \%$ of the women were housewives, and $8 \%$ of the women were commercial sex workers. All the women studied listed only heterosexual contact as their risk behavior. Of the men, 9\% of them said they had sex only with men, 17\% said with both men and women, and $65 \%$ said with female commercial sex workers. In terms of drug use, $2 \%$ of the patients reported they had used injection drugs at some point. At their initial medical visit to Hospital Rosales, over half of the 250 patients presented with a respiratory complaint or with diarrhea, $6 \%$ had pulmonary tuberculosis (TB), and 5\% had extrapulmonary TB. Of the 250 patients, 177 of them (71\%) had AIDS at the first medical visit. Of the 250, 138 of them (55\%) were lost to follow-up. Of the remaining 112 persons, 81 of them (72\%) were known to have died. Of those 81, 38 of them (47\%) died of unknown causes and 21 (26\%) died of TB.

Conclusions. The HIV-infected adults treated at the Hospital Rosales during the 19941998 period were usually infected through heterosexual sex, were symptomatic at the time of presentation, and were often lost to follow-up. Utilizing the results of our study and of other research, efforts to expand early intervention, counseling and testing, and targeted prevention activities should be strengthened.

Key words HIV, AIDS, risk factors, sexual behavior, El Salvador.

Similar to what has been described elsewhere in Latin America (1), the

\footnotetext{
1 London School of Hygiene and Tropical Medicine, London, United Kingdom. Send correspondence and reprint requests to: Elisa García Vázquez, Hospital Clinic, Villarroel 170, Barcelona 08036, Spain; telephone: 349322755 86; fax: 349345154 24; e-mail: elisag@eresmas.net

2 Hospital Rosales, San Salvador, El Salvador.

3 Infectious Diseases Physicians, Annandale, Virginia, United States of America.
}

HIV epidemic in El Salvador has expanded over the last decade. As of June 2001, 3934 cases of AIDS had been reported to the National AIDS Program (Programa Nacional de SIDA), with an additional 3626 reported cases of asymptomatic HIV infection (2). The United Nations estimates that approximately 20000 individuals may be infected with HIV in El Salvador, which has a population of approx- imately 6 million. Among the adult population, the estimated HIV prevalence is $0.6 \%(3)$.

Health care in El Salvador is provided through three principal health systems. Approximately $80 \%$ of the population depend on the Ministry of Public Health and Social Welfare (MOPHSW) (Ministerio de Salud Pública y Asistencia Social) for governmentsubsidized care that is provided to all 
citizens, regardless of their ability to pay, through a system of clinics and hospitals throughout the country. Through a separate system of clinics and hospitals, the Social Security Institute (Instituto Salvadoreño del Seguro Social) provides health care to a crosssection of the working class, who make up approximately $17 \%$ of the country's population. Funding of the Social Security Institute comes from a combination of government support, employer contributions, and employee withholdings (4). The wealthy and some individuals with private health insurance receive health services through private offices and hospitals, which have fee-for-service billing.

Within the MOPHSW system, HIVrelated health care is provided almost exclusively through Hospital Rosales, a 530-bed medical-surgical hospital within the National Medical Center in the capital, San Salvador. As of August 2002, approximately 400 patients with HIV infection were being managed in the ambulatory clinics at Hospital Rosales. Inpatients who are diagnosed with HIV are cared for by the general medical teams until they are transferred to the dedicated Infectious Diseases Unit (IDU). This 8-bed unit, which provides care exclusively to HIV-infected individuals, has been operational since 1994. In addition to transfers from the internal medicine wards, individuals with known HIV infection who require hospitalization are admitted directly to the IDU.

In addition, the Social Security Institute has had an HIV treatment program since 1995. Outpatients are seen in the ambulatory clinics of the Social Security oncology hospital (within the Social Security medical center complex in San Salvador) by two infectious disease specialists. Approximately 600 HIVinfected patients received care over the 1995-2000 period (Joaquín Viana, written communication, 24 July 2001).

There are also two nongovernmental organizations in El Salvador that provide HIV treatment, FundaSIDA and Grupo Atlacatl. FundaSIDA operates a small clinic through which medications are intermittently available. Grupo Atlacatl has a facility in
San Salvador through which HIVinfected patients can see an infectious disease physician for care.

In order to understand some of the clinical features of the HIV epidemic in El Salvador before antiretroviral therapy was available in the country, we retrospectively studied a cross-section of patients who received HIV-specific health services at Hospital Rosales over the 5-year period of 1994 through 1998. We decided to study this main MOPHSW hospital since the majority of the population in the country receives its health care through the MOPHSW facilities.

\section{MATERIALS AND METHODS}

We identified HIV-infected patients who received treatment at Hospital Rosales during the period of 1994 through 1998 in three ways, as described below.

First, all patients $(n=208)$ admitted to the Infectious Diseases Unit (IDU) from 1994 through 1998 were identified from a hand-written admission registry, which only provided the name of the patient and date of admission (as mentioned earlier, the IDU provides care exclusively to HIVinfected individuals). One of the authors (EGV) went through all the medical charts that could be located, 194 out of the 208 admitted patients.

Second, two of the authors (RAC and EGV) took a sampling of all other patients at Hospital Rosales who had a positive result on an HIV enzyme immunoassay (EIA) test performed at the Max Bloch Laboratory, which is the central laboratory of the National Medical Center. A total of 22356 serologic tests for HIV were performed at the Max Bloch Laboratory from 1994 through 1998. Of these, 668 were found to be positive. Of the 668 individuals, the authors randomly selected a total of 52 medical records to be reviewed and included in the study: 10 records each from 1994, 1995, and 1996, and 11 records each from 1997 and 1998.

Third, a total of 36156 blood samples from potential blood donors (from clinics all over El Salvador) were tested for HIV at the Max Bloch Laboratory. Of these, 93 tested positive for HIV. Only 6 of these individuals were seen in the clinical care setting at Hospital Rosales after receiving their HIV test results. Two of these records had already been included as patients admitted to the Infectious Diseases Unit. Thus, along with the 194 records from the IDU and the 52 records from the positive HIV tests, these 4 new records completed the total of 250 medical records that we used for our study.

We authors considered a patient to be infected with HIV if the HIV EIA test was repeatedly reactive in the setting of a clinical AIDS diagnosis, according to the PAHO-Caracas criteria (5), or after confirmation with a Western blot test in the absence of an AIDS diagnosis.

One of the authors (EGV) reviewed the 250 medical charts that we had selected, for demographic information, including age, sex, home setting (rural or urban), occupation, and risk factors for HIV transmission. Data were collected regarding the date of and the reason for the first medical visit to the Hospital Rosales IDU or ambulatory clinics, AIDS diagnosis at this first visit, the number of subsequent medical visits and hospitalizations, the presence of opportunistic infections, the use of prophylactic medications, the ultimate clinical outcome, and, if relevant, the date and cause of death. The number of medical visits was counted from the first medical visit to the last medical record (due to death or loss to follow-up) in the ambulatory clinics at Hospital Rosales.

\section{RESULTS}

Of the 250 persons whose medical records we reviewed, 167 of them (67\%) were men and 83 (33\%) were women. The mean age at the time of HIV diagnosis was 34 years for the men and 35 years for the women. Two hundred and sixteen were from an urban area $(86 \%)$, and $34(14 \%)$ were from a rural area.

Information about occupation was available for $127(76 \%)$ of the men 
and $78(94 \%)$ of the women. Of the 127 men, 63 of them $(50 \%)$ said they were day laborers. Of the 78 women, 59 of them $(76 \%)$ were listed as housewives. Six women ( $8 \%$ of the 78 ) and one man ( $1 \%$ of the 127$)$ were commercial sex workers.

Out of the 167 men, information on transmission risk factors were available for 156 of them. Out of the 167 men, 108 of them (65\%) admitted to having had sex with female commercial sex workers, 15 (9\%) said they engaged in sex only with other men, and $28(17 \%)$ said they had sex with both men and women.

Information on transmission risk factors was available for all 83 women. All of them listed only heterosexual contact as their risk behavior for acquiring HIV. With the exception of the commercial sex workers, the women admitted to having had between one and three sexual partners during their lifetime.

Three heterosexual and two bisexual men also admitted to injection drug use, accounting for $2 \%$ of the 250 persons in the study population.

Of the 250 patients, 151 of them $(60 \%)$ had a diagnosis of AIDS at the time of HIV diagnosis, 177 of them $(71 \%)$ at the time of their first medical visit, and 193 (77\%) as of the last recorded medical visit. One hundred twelve $(45 \%)$ received prophylaxis with trimethoprim-sulfamethoxazole at some point, and 3 patients received isoniazid. The most common reason for the initial medical visit was diarrhea, which was found in 82 patients (33\%). Other reasons are listed in Table 1.

Of 240 patients for whom information was available on the number of medical visits to Hospital Rosales (ambulatory clinics), the mean number of medical visits was 5.5 (range $=1-45$, standard deviation $(\mathrm{SD})=6.11$ ). Of the 231 for whom longitudinal hospitalization data were available, the mean number of hospitalizations was 1.35 (range $=0-9, \mathrm{SD}=1.31)$. Of 172 patients for whom the number of hospital days (total number of days for all hospitalizations) was available, patients stayed a mean of 35.6 days (range $=1-335, \mathrm{SD}=42.17$ ) in the hos-

TABLE 1. Reason for initial medical visit by 250 HIV-infected patients to Infectious Diseases Unit or to ambulatory clinics of Hospital Rosales, San Salvador, El Salvador, 1994-1998

\begin{tabular}{lrr}
\hline \multicolumn{1}{c}{ Diagnosis/Total } & No. & $\%$ \\
\hline Diarrhea & 82 & 32.8 \\
Routine initial medical visit & 43 & 17.2 \\
Diarrhea and respiratory symptoms & 24 & 9.6 \\
Respiratory symptoms and fever & 18 & 7.2 \\
Pulmonary tuberculosis & 15 & 6 \\
Extrapulmonary TB (+/- pulmonary) $^{\mathrm{a}}$ & 12 & 4.8 \\
Adenopathy or masses & 11 & 4.4 \\
Fever & 9 & 3.6 \\
Headache or focal CNS symptoms & & 3.2 \\
Cryptococcal meningitis & 8 & $<1$ \\
Kaposi sarcoma & 2 & $<1$ \\
Cytomegalovirus retinitis & 1 & $<1$ \\
Other HIV-related & 1 & 2 \\
Other not HIV-related & 5 & 2.8 \\
Missing diagnosis & 8 & 4.4 \\
$\quad$ Total & 11 & 100 \\
\hline
\end{tabular}

a Extrapulmonary TB (+/- pulmonary) = extrapulmonary TB with or without pulmonary TB (6 patients had only extrapulmonary TB, and 6 had both extrapulmonary and pulmonary tuberculosis).

b $\mathrm{CNS}=$ central nervous system.

TABLE 2. Identified cause of death among 81 HIV-infected patients at Hospital Rosales, San Salvador, El Salvador, 1994-1998

\begin{tabular}{|c|c|c|c|c|}
\hline \multirow[b]{2}{*}{ Cause of death/Total } & \multirow{2}{*}{$\frac{\text { Women }}{\text { No. }}$} & \multirow{2}{*}{$\frac{\text { Men }}{\text { No. }}$} & \multicolumn{2}{|c|}{ Women + men } \\
\hline & & & No. & $\%$ \\
\hline Unknown & 13 & 25 & 38 & 46.9 \\
\hline Tuberculosis & 6 & 15 & 21 & 25.6 \\
\hline Respiratory insufficiency & 1 & 5 & 6 & 7.4 \\
\hline Histoplasmosis & 1 & 2 & 3 & 3.7 \\
\hline Abdominal sepsis & 2 & 1 & 3 & 3.7 \\
\hline Meningoencephalitis & 1 & 2 & 3 & 3.7 \\
\hline Tuberculosis and histoplasmosis & 1 & 1 & 2 & 2.5 \\
\hline Drug-related hepatitis & 1 & 1 & 2 & 2.5 \\
\hline Cryptococcal meningitis & 2 & 0 & 2 & 2.5 \\
\hline Non-Hodgkin lymphoma & 0 & 1 & 1 & 1.2 \\
\hline Total & 28 & 53 & 81 & 100 \\
\hline
\end{tabular}

pital. The mean time for each hospitalization was 24 days (range $=1-335$, $\mathrm{SD}=34.3$ ), with a median of 15 and a mode of 10 .

Of the 250 patients, 138 of them $(55 \%)$ were lost to follow-up. Of the remaining 112 , 81 of them $(72 \%)$ were known to have died. Of these 81,21 $(26 \%)$ died of tuberculosis. Thirtyeight $(47 \%)$ died of unknown causes. Other causes of death are listed in Table 2.

\section{DISCUSSION}

Several epidemiological features of this group of patients are noteworthy in terms of their likely implications for future efforts to deal with the HIV epidemic in El Salvador: one-third of the infected patients were women, most of the study population acquired the illness through heterosexual contact, and $60 \%$ of the patients had AIDS at the time of their initial diagnosis of 
HIV infection $(71 \%$ at the time of their first medical visit). Although specific income data were not available, the majority of the patients appeared to be from the lower socioeconomic strata, including men working as day laborers. Over half of the patients were lost to follow-up; of the remaining persons, nearly three-quarters of them had died by the time of our analysis. There were no changes in these epidemiological features over the study period.

As the principal medical-surgical teaching hospital within the MOPHSW of El Salvador, Hospital Rosales serves primarily the poor and those without any other form of available health care. The Hospital Rosales is the only location within the MOPHSW that has HIV specialists. The other major health institution, the Social Security Institute, estimates that approximately 600 HIV-infected patients had been under the care of its clinicians over the 19952000 period. In a country with an estimated 20000 HIV-infected adults and with 3934 reported cases of AIDS as of June 2001, it is likely that HIV is both underrecognized and underreported and also that a large majority of symptomatic adults never enter the health care system for their HIV infection. According to our data, of those who did enter the health care system, they usually did so late in the course of their disease and most had had a poor outcome. This situation did not change over the course of our 1994-1998 study period.

This study is the first report in an international journal on the clinical and demographic features of HIV-infected adults in a clinical care setting in El Salvador. Our sample is probably representative of HIV infection among all medically indigent patients in clinical care during the years under study, since the majority of these persons would have received care at Hospital
Rosales and thus been captured in our data. The demographics of our patients are similar to the demographics of persons who have been reported with AIDS in El Salvador (1-4). Unfortunately, we could not find any published data on patients receiving HIV care in the Social Security Institute. Whether these Hospital Rosales patients reflect the demographics of individuals newly infected with HIV after 1998 in El Salvador is difficult to ascertain since information about asymptomatic HIV infection is just beginning to be collected and reported in the country.

Our data suggest that HIV in El Salvador was primarily transmitted heterosexually, even in the late 1980s and early 1990s, when the Hospital Rosales patients whom we studied would have been most likely to have acquired their infection. However, the stigma associated with men having sex with men may have played a role in underreporting of this risk factor in our population.

A major limitation of our data is that they were collected retrospectively and that certain elements of interest, such as some long-term follow-up details, were not available in all the medical records. The clinical care received by the patients also reflected HIV care during the first 5 years that the Infectious Diseases Unit was open. Over that 1994-1998 period, care was mostly palliative, diagnostic studies were often not pursued, and patients were often sent home or admitted to the hospital to die.

Since 1998 the Infectious Diseases Unit has had a medical director who is an infectious diseases specialist. Formal teaching rounds are conducted, dedicated staff are assigned to the unit, auxiliary staff participate in the care and monitoring of HIV-infected outpatients, and more diagnostic evaluations are being pursued. Most antibacterial agents are now available, as are also medications for tuberculosis and most fungal and parasitic infections. Through the first half of 2000, antiretroviral agents were not available through the Ministry of Public Health and Social Welfare (6). However, one of the authors (RAC) began a pilot project in late 2000 to study the feasibility of using these medications in the outpatient setting. Clinical care since 1998 has begun to focus more on outpatient management, on the use of prophylactic medications to prevent opportunistic infections, and HIV prevention counseling, in an attempt to decrease the rate of transmission and therefore the number of new HIV cases.

Future evaluations of the clinical and demographic features of HIV infection within the MOPHSW or the Social Security Institute should probably be based on a prospectively designed data set and include the clinical experiences of some individuals on antiretroviral therapy. Future studies of patients in El Salvador should collect more data on health-seeking behaviors. Information on knowledge and behavior related to HIV/AIDS is essential in identifying the population at risk of HIV infection as well as in assessing changes over time as a result of prevention efforts. There is no information available on prevention indicators in El Salvador. Gathering these various types of information and building this new base of knowledge could help strengthen efforts to expand early intervention, testing and counseling, and targeted HIV prevention activities.

Acknowledgments. This work was supported by a grant that Elisa García Vázquez received from the London School of Hygiene and Tropical Medicine as part of the Project for her Master of Science in Infection and Health in the Tropics (1998-1999). 


\section{REFERENCES}

1. Pan American Health Organization. AIDS surveillance in the Americas, biannual report. Washington, D.C.: PAHO; 2000.

2. El Salvador, Ministerio de Salud Pública y Asistencia Social. Programa nacional de vigilancia y control de ETS/VIH/SIDA. San Salvador: Ministerio de Salud Pública y Asistencia Social; 2001.

3. Joint United Nations Programme on HIV/ AIDS. Report on the global HIV/AIDS epidemic: June, 2000 [Internet page]. Availa- ble from: http://www.unaids.org/epidemic update/report/index.html. Accessed February 2002.

4. Pan American Health Organization. Country health profile: El Salvador [Internet page]. Available from: http:/ / www.paho.org. Accessed February 2002.

5. Gallant JE, Eldred LJ, Leslie JM, Chaisson RE, Quinn TC. Impact of the 1993 revision of the CDC case definition on the performance of the
WHO and PAHO clinical case definitions for AIDS. AIDS 1993;7:1396-1397.

6. Wheeler DA, Arathoon EG, Pitts M, Cedillos RA, $\mathrm{Bu}$ TE, Porras GD, et al. Availability of HIV care in Central America. JAMA 2001;286: 853-860.

Manuscript received 26 March 2002. Revised version accepted for publication on 26 November 2002

RESUMEN Objetivos. Describir las características clínicas y demográficas de la epidemia de infección por VIH en El Salvador antes de que se dispusiera de una terapia antirretroviral en ese país.

Características clínicas Método. Estudio retrospectivo de pacientes infectados con el VIH atendidos en el y demográficas de la infección Hospital Rosales - una institución hospitalaria docente de San Salvador, El Salvadorentre 1994 y 1998. Se hicieron resúmenes de las historias clínicas de 194 de los 208 pacientes ingresados en la Unidad de Enfermedades Infecciosas del Hospital (14 historias clínicas no pudieron ser localizadas). También se tomó una muestra de otros pacientes adultos infectados por el VIH que fueron atendidos en otras áreas del hospital. Resultados. De los 250 pacientes cuyas historias clínicas pudieron ser estudiadas, $67 \%$ eran hombres y $86 \%$ procedían de zonas urbanas. La edad promedio en el momento del diagnóstico de la infección por el VIH fue de 34 años. De los hombres, 50\% eran trabajadores diurnos; $76 \%$ de las mujeres eran amas de casa y $8 \%$ se dedicaba al comercio sexual. Todas las mujeres estudiadas mencionaron el contacto heterosexual como su única conducta de riesgo. De los hombres, 9\% expresaron que tenían relaciones sexuales solo con otros hombres, $17 \%$ manifestaron que lo hacían tanto con hombres como con mujeres y $65 \%$ afirmaron haber mantenido relaciones sexuales con prostitutas. En cuanto al uso de drogas, $2 \%$ de los pacientes reconocieron haber utilizado drogas intravenosas en algún momento. En su visita inicial al Hospital Rosales, más de la mitad de los pacientes presentaban problemas respiratorios o diarreas, $6 \%$ tenían tuberculosis (TB) pulmonar y 5\% TB extrapulmonar. De los 250 pacientes, 177 (71\%) tenía sida en el momento de su primera consulta y a $138(55 \%)$ no se les pudo terminar el seguimiento. De los restantes 112 pacientes se sabe que $81(72 \%)$ fallecieron. De ellos, $21(26 \%)$ murieron de TB y de los restantes 38 (47\%) se desconoce la causa de muerte.

Conclusiones. Los adultos infectados por el VIH atendidos en el Hospital Rosales entre 1994 y 1998 adquirieron la infección mediante prácticas heterosexuales, presentaban síntomas en el momento de su primera consulta y abandonaron el seguimiento. Estos hallazgos y los resultados de otras investigaciones deben utilizarse para desarrollar acciones de intervención temprana y ampliar los servicios de asesoramiento y de laboratorio, asi como para fortalecer las acciones de prevención. 